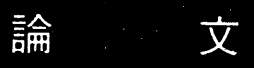

\title{
A Consideration on the Behavior of Capillary Flow Fracture on the Basis of Distribution and Vibration of Pressure in Reservoir of Polymer Melt
}

by

\author{
Yasushi Oyanagi and Yukisaburo Yamaguchi \\ (Kogakuin University, 1-24-2 Nishishinjuku, Shinjuku-ku, Tokyo)
}

\begin{abstract}
The objective of the present study is to confirm the hypothesis presented by one of the authors that the initiating mechanism of melt flow fracture is affected by the behaviors of distribution and vibration of pressure in shear flow field of high density polyethylene melts. It was recognized that the pressure at reservoir wall and in the reservoir, which was measured in rectangular direction with the flow direction, varied with the positions of measurement points i.e., the pressure distribution curves were similar to the profile of shear rate distribution curves under normal flow region or low shear rate region. The mean pressure in a pressure distribution curve increases with the increase of shear rate. The pressure vibrations occurred at particular measurement points, which were presented in the previous paper as fracture region at the critical condition of normal flow to spiralling flow under moderate shear rate. At these positions of measurement points the vibration phenomena generally initiated near the capillary inlet under low shear rate, and moved to the reservoir wall from the reservoir axis with the increase of shear rate and ultimately, disappeared with further increase of shear rate. The larger melt index of high density polyethylene, the larger pressure vibration becomes. Both flow rate excess induced by the melt flow fracture and the effects of L/D of capillaries upon flow rate excess can be explained by the hypothesis utilizing the particular fracture surface in shear flow field.
\end{abstract}

\section{リザーパー内圧分布とその変動に基づく溶融高分子の 細孔流動破壊についての一考察}

\author{
大 柳康・山 口 章三郎*
}

（原稿受理：1974年 9 月 4 日）

\section{1. 粕} 曹

さきに高密度ポリエチレンなどの溶融高分子の細孔流動破壊性 について, 直接観察結果に基ついた一つの発生機構論 ${ }^{1)}$ を提唱し た.

との中で, とくに線状高分子構造をもつものでは, その構成 分子形態上, せん断応力による分子相互間の相対的ずれが発生し 易く,さらに高速流動下では, との局部的なずれが巨視的にまで 成長し,リザーバー内のみならず, 細孔内部にまで発達した形態 をとるようになる，すなわち，流動分子間のすべり面の発生とも

\footnotetext{
* 工学院大学 東京都新宿区西新宿 1-24-2
}

考えられるような特異面の発生とその形態が，押出物形状にわけ ろ spiralling や脈動性に関連を及ぼすととなどを指摘した。 また とのような局部的状態変化は, 瞬間弾性効果 ${ }^{23)}$ などから, 正常 流から異常流への過度現象において, 圧力などの状態に変動をと もなうととを提示した。

これら溶融破壊性の発生因および発生機構については, 従来か

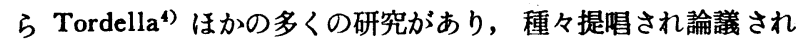
てきだ).

しかし，すべての現象を十分に説明し得るに足りる汎用定説は まだ得られていないのが現状のようである．とれらの説の中で， とくに注目すべきものの一つとして slip-stick 説があげられる. 
これはおもに Cogswell-Lamb ${ }^{6)}$ ほかによって提唱されたもの で，その概要は，流動体がもつ弾性効果その他が引き金になって， ある程度せん断応力が増した状態下でひずみが不平衡化し，その ため細孔出口近くの壁面で slip を生じ，それに付随した stick 現 象をもたらし，押出物形状に不定形を形成するというものである. この説にもある種の罗当性が認められるが, Bagley ${ }^{7)}$, Tordel$\mathrm{la}^{4) 8)}$ 以後の研究結果，たとえば White-Ballenger ${ }^{9)}, \operatorname{Han}^{10)}$ よお

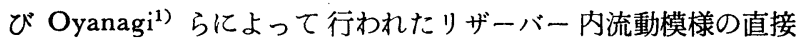
観察では, リザーバー内流路急変部にその発生因が認められ, と くに筆者らは，その発生個所が壁面よりむしろ少し内部にあるて とを提唱している，すなわち，Cogswell らの slip-stick 説と発 生場所などで本質的に相違している。 てれらの現象はかなり複雑 であり，また材料の多種性も加わるため，より多くの現象的把握 を必要とするのはいうまでもない.

本研究はとのような観点から, 前報1)11)に引続いて, 溶融流動 破壊性をより現象論的に確かめるべく，リザーバー内圧の分布状 態およびその変動を 3 種の高密度ポリエチレンに例をとって, 種 々の流動条件下で実験的に求め, 上記流動破壊機構との関連性を 検討するとともに，乙れに付随した一，二の現象を実験的に検討 した.

\section{2. 実験}

$2 \cdot 1$ 試料

用いた試料は前報 ${ }^{1)}$ と同じく，メルトインデックス（M. I .) をそれぞれ異にする 3 種の高密度ポリエチレンで，その詳細を Table I 亿示す.

$2 \cdot 2$ 内圧測定装置と測定法

本装置の外観（一部）を Fig. 1，またそのリザーバー部の内

Table I Materials used

\begin{tabular}{lcccc}
\hline Material & $\begin{array}{c}\text { Gommercial } \\
\text { grade No. }\end{array}$ & $\begin{array}{c}\text { Average } \\
\text { molecular weight }\end{array}$ & Melt index \\
& b) \\
High density & HIZEX-3300F & about $6.5 \times 10^{4}$ & 0.90 \\
polyethylene & HIXEZ-5000F & " 6.5 " & 0.50 \\
& HIZEX-7000F & " $12.0 "$ & 0.04 \\
\hline
\end{tabular}

a) by viscometer

b) by ASTM D1238-65T

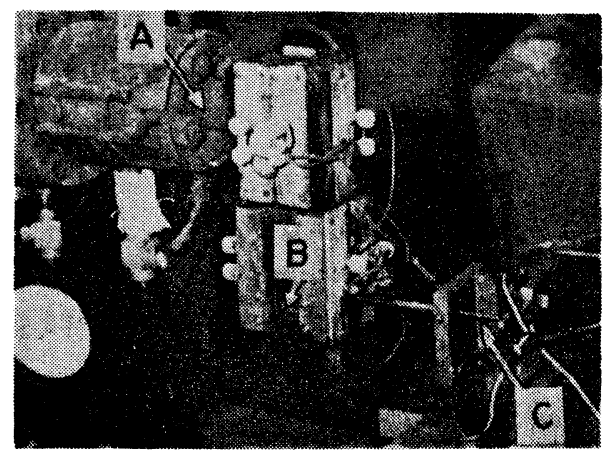
A : Extruder die head
B : Reservoir
G : Pressure measurement pin

Fig. 1. The out-side view of reservoir and its pressure measurement system.

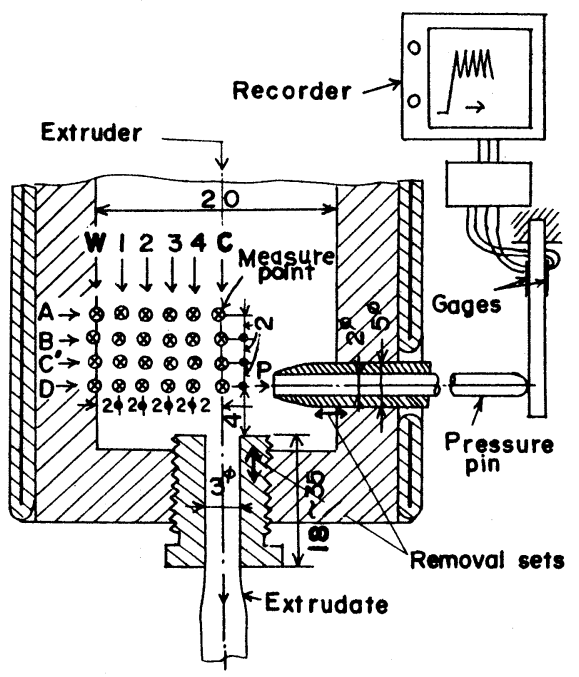

Fig. 2. The schematic figure on pressure measrement points and measurment apparatus.

部構造と圧力測定装置の概略を Fig. 2 亿示す. 溶融樹脂は, ス クリュ径 $40 \mathrm{~mm}$ の押出成形機から一定スクリュ回転速度のもと で, ダイヘッドに連結された一定温度のリザーバー $(20 \times 20 \mathrm{~mm}$ 正方形断面）内に送りこまれる。リザーバー最下端には，ねじに よって適当にその位置を加堿できるダイがあり，その細孔から溶 融樹脂は大気中に自由放出される。

リザーバー内壁面わよび樹脂内部の圧力は, 流れ方向に対して 直角方向に, $2 \mathrm{~mm}$ 径の感圧ピンを 直接樹脂に接触させ, それ にかかる樹脂圧を片持はり式圧力変換器を介して記録計に記録し た. 感圧ピンとホルダ間の摺動面には, シリコーングリスを注入 し, 摩擦と樹脂の洩れとを低娍させた。 なお， との圧力変換器 （自家製）は，検定実験によれば，実験範囲内で，圧力一出力関係 に正比例的直線関係が示された。

リザーバー壁面わよび内圧の測定個所は, 同一流動条件下で, ダ イのねじわよびリザーバー内に插入*1 した感圧ピンホルダの位置 を壁面から中心部にまで種々に変えるととによって変化し，Fig. 2 の囚印の示すように，流れ方向に $2 \mathrm{~mm}$ 間隔で 4 レベル (Fig. 2 の A, B, G', D の 各測定点), リザーバー壁面から中心軸線 上に至る流路の片側で, $2 \mathrm{~mm}$ 間隔に 6 レベル (Fig. 2 の W, 1, $2,3,4, G)$, 計24個所を測定した。 との各測定点の圧力は, 測定 点記号を下付のサフィクスとした $P_{W A}, P_{C^{\prime}{ }_{3}} \cdots$ のように表わした。 本実験に使用したダイは, 径 $3 \mathrm{~mm}$, 長さ $18 \mathrm{~mm}(L / D=6)$ および同径で長さが $35 \mathrm{~mm}(L / D=11.7)$ の細孔寸法をもったス テンレス・スチールの 2 種である．また試験温度はリザーバー壁 面近くに感熱部をもつ温度計で $180 \sim 200^{\circ} \mathrm{C}$ の範囲 $\left( \pm 2^{\circ} \mathrm{C}\right)$ とし, とくに標準試験温度を $185 \sim 190^{\circ} \mathrm{C}$ とした。

押出成形機のスクリュ回転速度 $N(\mathrm{rpm})$ は，14，18.5, 26 お よび35の 4 段階に変えた。.またその流出量は単位時間あたりの押 出重量から求め, さらに次式によって細孔壁面での見脚けのせん 断速度 $\dot{\gamma}_{w}{ }^{\prime}\left(\mathrm{sec}^{-1}\right)$ を算出した。

*1 感圧ピンをリザーバー内に挿入するととによる流動状態の変 化は，多少あるあのと考えられるが，今回はホルダの抵抗を できるだけ少なくするようにして，その影整は考虑しなかっ た. 


$$
\dot{\gamma}_{w}^{\prime}=\frac{32 Q}{\pi D^{3}} \quad\left(\sec ^{-1}\right)
$$

ただし，Qは容積流出量 $\left(\mathrm{cm}^{3} / \mathrm{sec}\right), D$ は細孔径（cm) である.

$$
\text { 3. 結 }
$$

果

\section{$3 \cdot 1$ 各試料の $\tau_{w}{ }^{\prime}-\gamma_{w}{ }^{\prime}$ 関係線図亡本実験範囲との対応}

各実験試料の細孔壁面での見掛けのせん断応力 $\tau_{w}{ }^{\prime}=(p D / 4 L$, $\left.\mathrm{kg} / \mathrm{cm}^{2}\right)$ と同場所における見掛けのせん断速度 $\dot{\gamma}_{w}{ }^{\prime}$ との関係を Fig. $3\left(\mathrm{H}_{\mathrm{z}}\right.$ 3300F), Fig. $4\left(\mathrm{H}_{\mathrm{z}}\right.$ 5000F) および Fig. $5\left(\mathrm{H}_{\mathrm{z}} 7000\right.$ F) に示す。これらの図はいずれも $L / D=40$ の標準ダイ $(D=$ $1.28 \mathrm{~mm}, L=51 \mathrm{~mm}$, 焼結合金, 流入角 $90^{\circ}$ ) をもつ Instron Capillary Rheometer (Instron 社，2ton) で得た結果である。乙れ らの図中に示す s. および m.f. の記号は, 既報1) と同様に, 押出 物形状から判定した spiralling（規則状らせん構造体）と melt fracture（不規則状不定形構造体）の生じたものを示す。

試料別にみると，乙れら $\tau_{w^{\prime}}{ }^{\prime}-\dot{\gamma}_{w}{ }^{\prime}{ }^{\prime}$ 線図における曲線の傾きは, 低せん断速度領域でほぼ直線で表わすことができ，また次式で表 わすべき法則 ${ }^{15)}$ の定数 $n$ は, M.I.の小さいものほど一般に大きい ととがわかる。

$$
n=\frac{\log \dot{\gamma}_{w}^{\prime}}{\log \tau_{w}^{\prime}}
$$

また高せん断速度領域では，線状高分子構造物の特徽の一つと して, 温度が低いほど低い $\dot{\gamma}_{w}{ }^{\prime}$ で生じる流出量またはせん断速度 の急増現象")がある.とくに $\mathrm{H}_{\mathrm{z}} 3300 \mathrm{~F}$ と $\mathrm{H}_{\mathrm{z}} 7000 \mathrm{~F}$ において著 しい流出量の過多現象がみられる。

てれらの $\tau_{w}{ }^{\prime}-\dot{\gamma}^{\prime}{ }_{w}$ 線上で, 内圧を測定した本実験範讲を対応さ せてみると，スクリュ回転速度を 4 段階に変えた場合の $\dot{\gamma}_{w}{ }^{\prime}$ は， 同じ流動条件下でも溶融粘度の高低から試料によって多少の差は あるが，その上限および下限を求めると, 以後の実験結果にも示

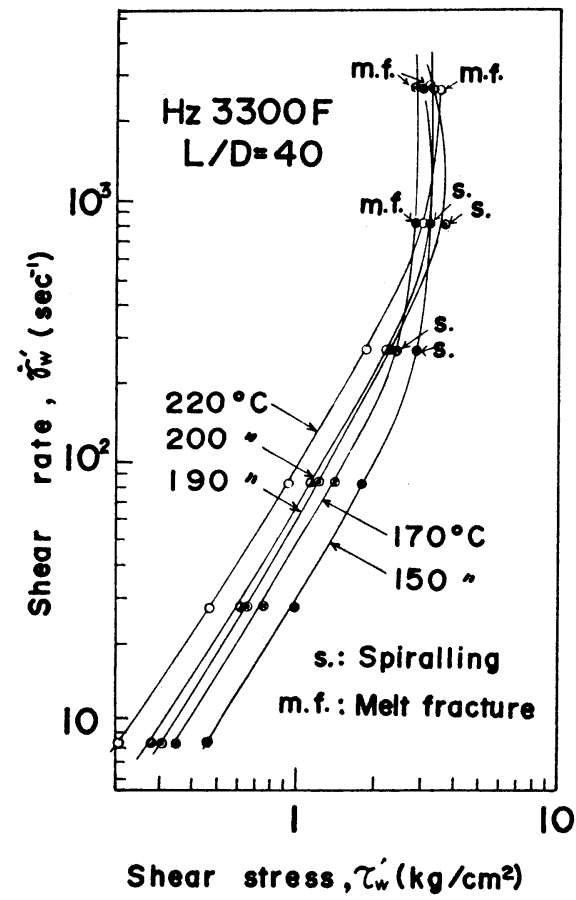

Fig. 3. The relation between apparent shear stress $\tau_{w}{ }^{\prime}$ and apparent shear rate $\dot{\gamma}_{w}^{\prime}$ at the capillary wall of Instron Capillary Rheometer for $\mathrm{Hz} 3300 \mathrm{~F}$.

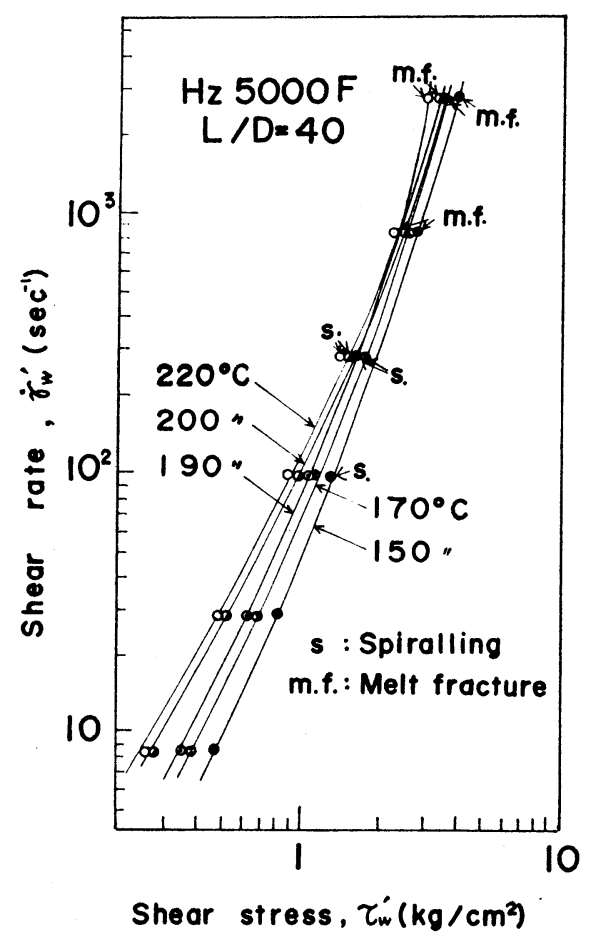

Fig. 4. The relation between apparent shear stress $\tau_{w}{ }^{\prime}$ and apparent shear rate $\dot{\gamma}_{w}{ }^{\prime}$ at the capillary wall for $\mathrm{H}_{\mathbf{z}}$ $5000 \mathrm{~F}$.

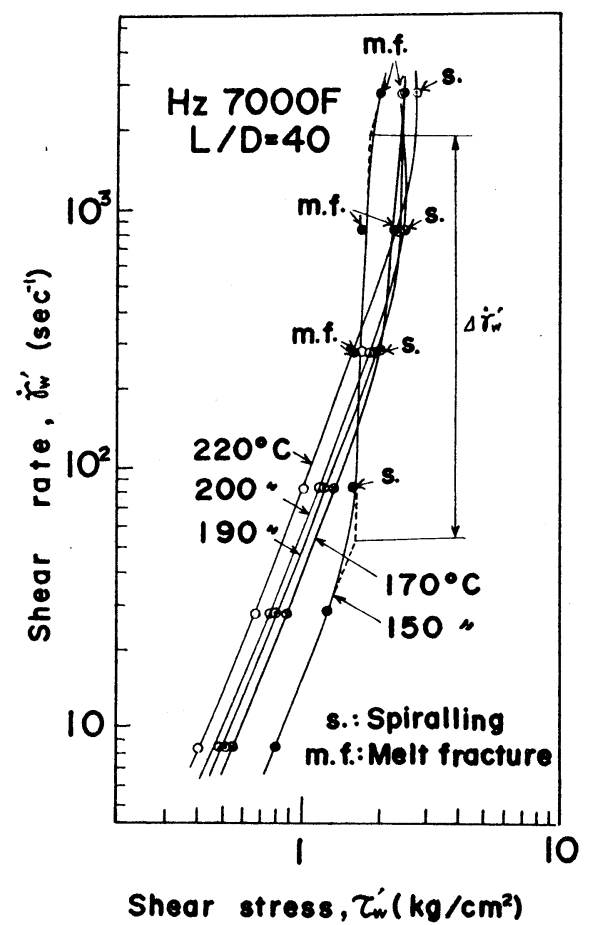

Fig. 5. The relation between apparent shear stress $\tau_{w}{ }^{\prime}$ and apparent shear rate $\dot{\gamma}_{w}^{\prime}$ at the capillary wall for $\mathrm{H}_{\mathbf{z}} 7000 \mathrm{~F}$.

されるように 300 1000 $\mathrm{sec}^{-1}$ にあるため，一般に各試料とも spiralling $と$ melt fracture の発生領域（温度が低い場合）また は正常流動から spiralling への遷移領域内（温度が高い場合）に あるととがわかる。 


\section{$3 \cdot 2$ リザーバー内圧変動と内圧分布の一般的形態}

Fig. 6 はチャート紙上に記録された内圧変動例である.

一般に測定された圧力は，スクリュ回転速度が大きいほど総体 的に増すが，壁面わよび内部における圧力は，測定個所によって 相当に変化する. その測定圧の分布状態の例を, Fig. 7 および Fig. 8 に示す. 乙れらの図は, $\mathrm{H}_{\mathrm{z}} 5000 \mathrm{~F}$ の試料, $200 \sim 195^{\circ} \mathrm{C}$, $L / D=11.7$ の紐孔を用いた場合の各測定点での圧力を，スクリュ 回転速度別に三次元的直角座標表示をしたものである. 図中に示 す縦の細線 $(N=35 \mathrm{rpm}$ の図参照) は, その測定点において, 圧 力に変動を伴うこと, またその線の長さはその変動幅を示したも のである.

この圧力変動は, 押出物形態上, spiralling を生じた場合には, 必然的に付随する一般的な共通結果 ${ }^{1)}$ であるが，その発生個所は, 試料や試験条件によって, 異なっていてしかも局所的に限られる.

すなわち各測定点のいずれもがすべて変動を生じるとは限って いない. spirallang の発生限界を境として, その上下の $\dot{\gamma}_{w}{ }^{\prime}$ 領 域で, 測定圧には断首または不連続性を生じる。 そしててれら圧 力が変動する個所とその $\dot{r}^{\prime}{ }^{\prime}$ 増加にともなう推移は，とれらの発

(a)

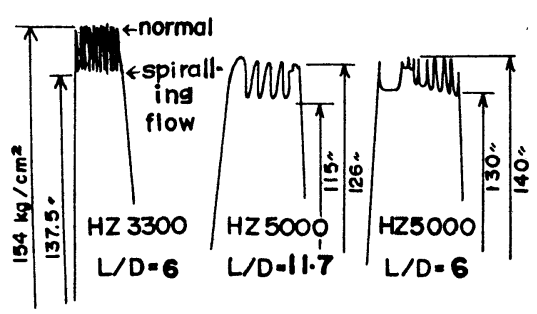

Fig. 6. Some results on the inner-pressure vibration phenomena under a constant shear flowing

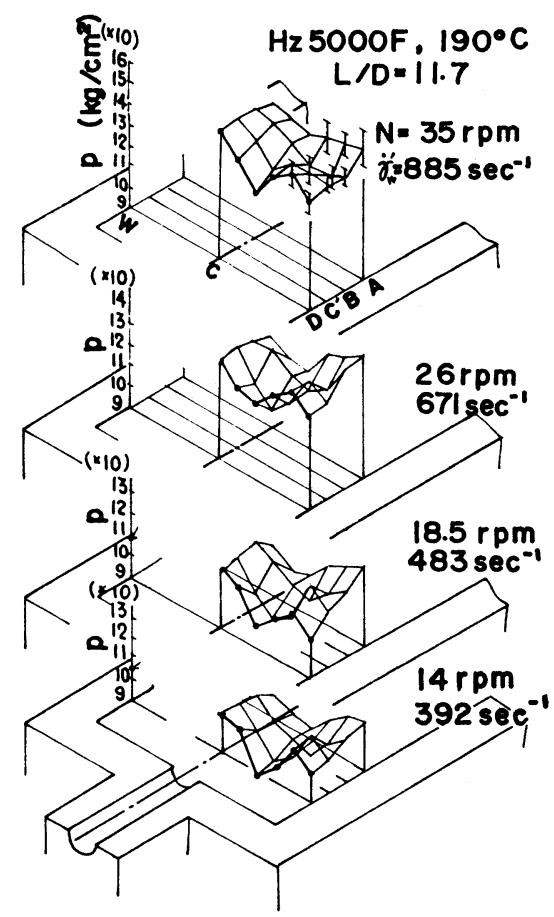

Fig. 7. The inner-pressure distributions at various measurement points in the reservoir under various shear rates for $\mathrm{Hz} 5000 \mathrm{~F}$ at $190^{\circ} \mathrm{C}$.
生因を検討する上に重要な一つの手がかりを与えている. 以下てれらについて,より詳しく検討した結果を示そう。 $3 \cdot 3$ 各試料の圧力分布形態とその $\gamma_{w}^{\prime}$ 依存性 標準温度 $\left(185 \sim 190^{\circ} \mathrm{C}\right)$ における各試料のリザーバー内中心軸 を含む平面内での各レベルでとの圧力分布状態を Fig. $9\left(\mathrm{H}_{2}\right.$

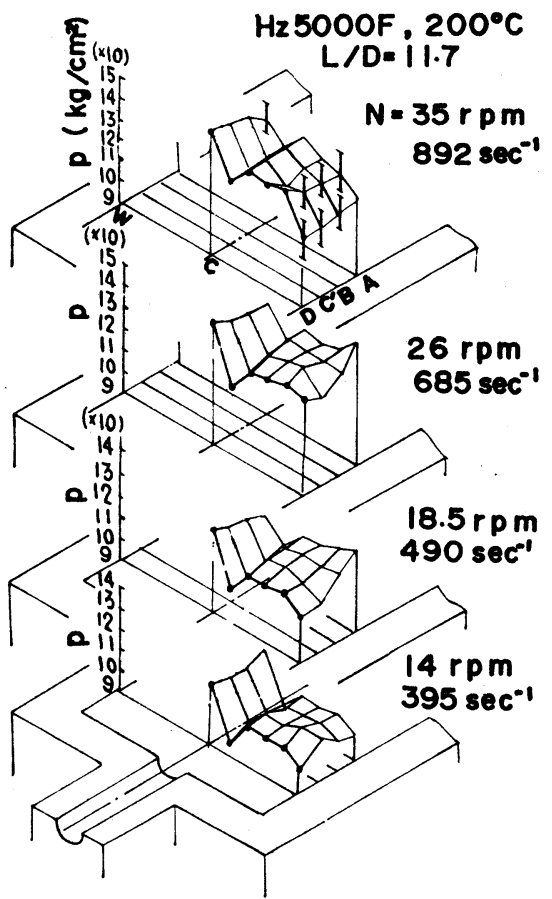

Fig. 8. The inner-pressure distributions at various measurement points in the reservoir under various shear rates for $\mathrm{Hz} 5000 \mathrm{~F}$ at $200^{\circ} \mathrm{C}$.

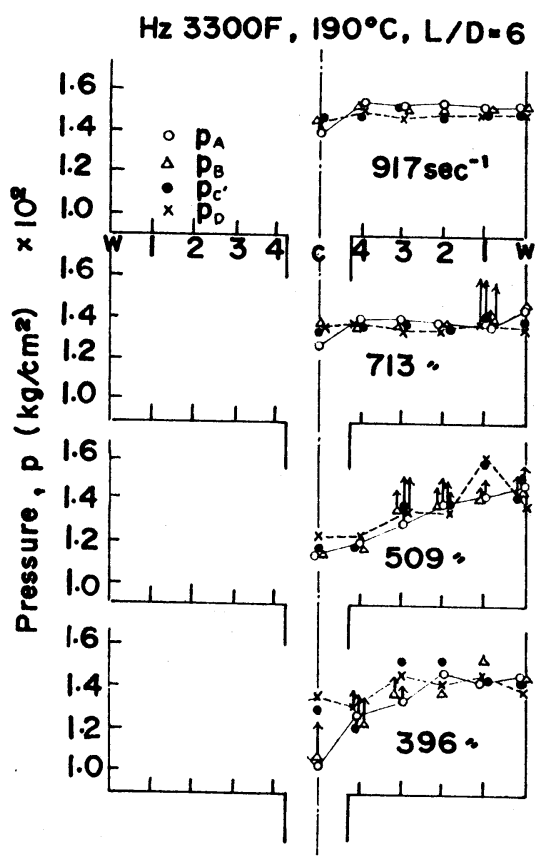

Fig. 9. The inner-pressure distributions at various measurement points in the reservoir under various shear rates for $\mathrm{Hz} 3300 \mathrm{~F}$ at $190^{\circ} \mathrm{C}$. 
3300F), Fig. $10\left(\mathrm{H}_{\mathrm{z}}\right.$ 5000F) および Fig. $11\left(\mathrm{H}_{\mathrm{z}} 7000 \mathrm{~F}\right)$ 亿示す. 図の繸矢印は，その測定点での圧力変動とその幅とを示している. とれらの圧力分布曲線から，一般的傾向として，下記のととが いえる.

すなわち，(1)圧力分布は $\dot{\gamma}_{w}{ }^{\prime}$ の大小で変化する，一般には $\dot{\gamma}_{w}{ }^{\prime}$ の小さいものほど圧力分布における高低の差が著しいが， $\dot{\gamma}_{w}{ }^{\prime}$ の

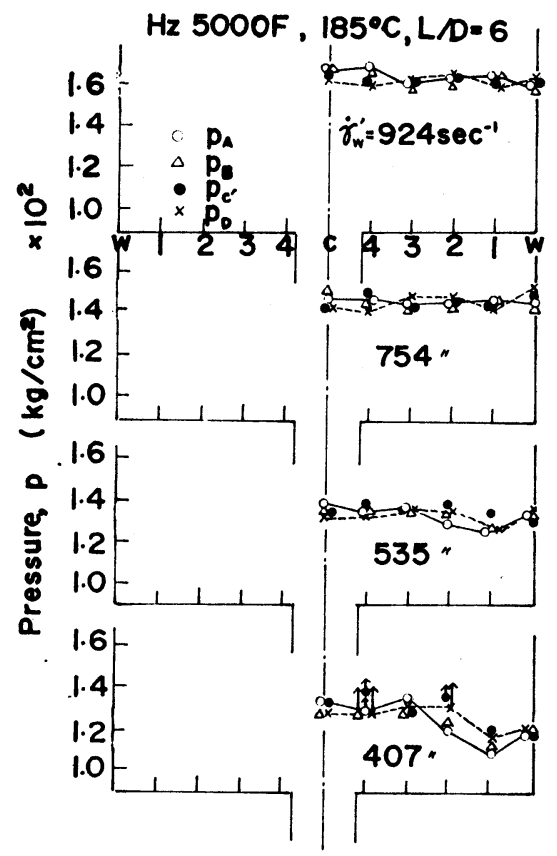

Fig. 10. The inner-pressure distributions at various measurement points in the reservoir under various shear rates for $\mathrm{Hz} 5000 \mathrm{~F}$ at $185^{\circ} \mathrm{C}$.

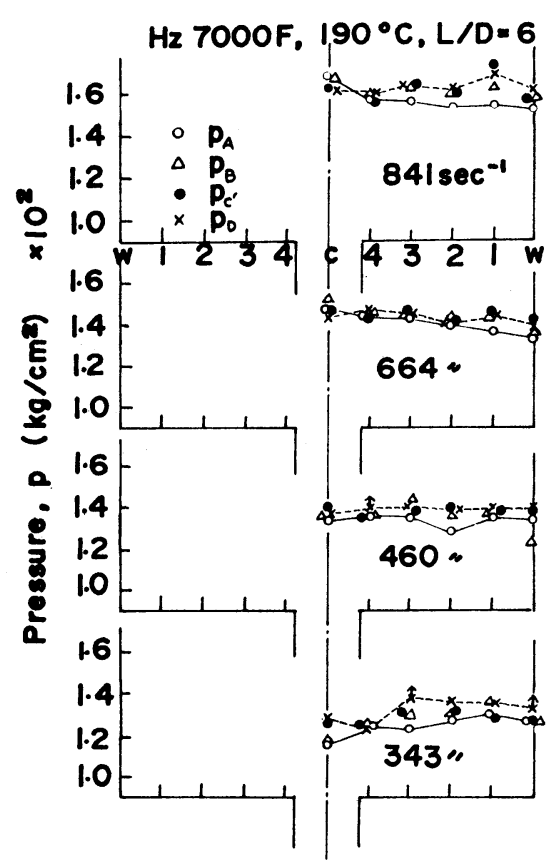

Fig. 11. The inner-pressure distributions at various measurement points in the reservoir under various shear rates for $\mathrm{Hz} 7000 \mathrm{~F}$ at $190^{\circ} \mathrm{C}$.
増加にともなって，漸次その差は少なくなる．乙の傾向は $\mathrm{H}_{\mathbf{z}}$ $3300 \mathrm{~F}$ において顕著であるが, $\mathrm{H}_{\mathrm{z}} 5000 \mathrm{~F}$ と $\mathrm{H}_{\mathrm{z}} 7000 \mathrm{~F}$ とではそ れほどではない.

(2) Fig. 7 と Fig. 8 および Fig. 10 を比較するてとによって は，一般に L/D が大きいほど同じ測定レベル（測定点 $\mathrm{A} \sim \mathrm{D} ）$ での最高と最低との圧力差は大きくなる傾向にある。

(3) Fig. 9 の $\mathrm{H}_{\mathbf{z}}$ 3300F の結果が示すように, 圧力振幅をとも なう場所は， $\dot{r}_{w}{ }^{\prime}$ の低い場合では流入端部に近い中心軸部分に生 じるのに対して，漸次 $\dot{r}_{w}{ }^{\prime}$ が増加する場合には，それとともに壁 面に移行して行く現象が認められ， $\dot{r}_{w}{ }^{\prime}=900 \sim 1000 \mathrm{sec}^{-1}$ のよう な高い $\dot{r}_{w}^{\prime}$ のもとでは，もはや消失してしまう，ての傾向は，い ずれの試料においても同じように認められるが, $\mathrm{H}_{\mathbf{z}} 5000 \mathrm{~F}$ と $\mathrm{H}_{\mathbf{z}}$ $7000 \mathrm{~F}$ の場合には， $\mathrm{H}_{\mathrm{z}} 3300 \mathrm{~F}$ ほど著しいものではない。すすなわ ち, 圧力振幅は, 試料の M.I. および分子量などによって相当に 異なってくる。

(4) 試験温度が高くしかも $L / D$ が大きい場合には, Fig. 7, 8 および10を比較するとわかるように，軸心部での圧力に上向きの 凸部を生じ，中心部と壁面間に大きな谷部を生じる傾向がある.

Fig. 12 および Fig. 13 はそれぞれ，スクリュ回転速度別（た だし，試料により $\dot{\gamma}_{w}{ }^{\prime}$ に多少の差がある）に三つの試料をパラメ 一タとして $\mathrm{p}_{\mathbf{A}}$ と $\mathrm{p}_{\mathrm{D}}$ を比較したものである.

一般に同種の試料においては, その流動曲線 (Fig. 3〜 5) に示 すように, 分子量が大きい試料ほどnが大きく, spiralling およ び melt fracture に対する限界せん断速度が低下する ${ }^{1) 4)}$. 同一ス クリュ回転速度下（たとえば，Fig. 12 の $N=14 \mathrm{rpm}$ の場合など） において, nの大きい $\mathrm{H}_{\mathrm{z}} 5000 \mathrm{~F}$ および $\mathrm{H}_{\mathrm{z}} 7000 \mathrm{~F}$ ではいずれも この条件ですでに spiralling または melt fracture 発生限界領 域内にあるため， $n$ が小さく，したがって限界せん断速度が大き い $\mathrm{H}_{\mathrm{z}} 3300 \mathrm{~F}$ の同じ条件下での壁圧 $\mathrm{p}_{\mathrm{w}}$ よりかえって低くなるて

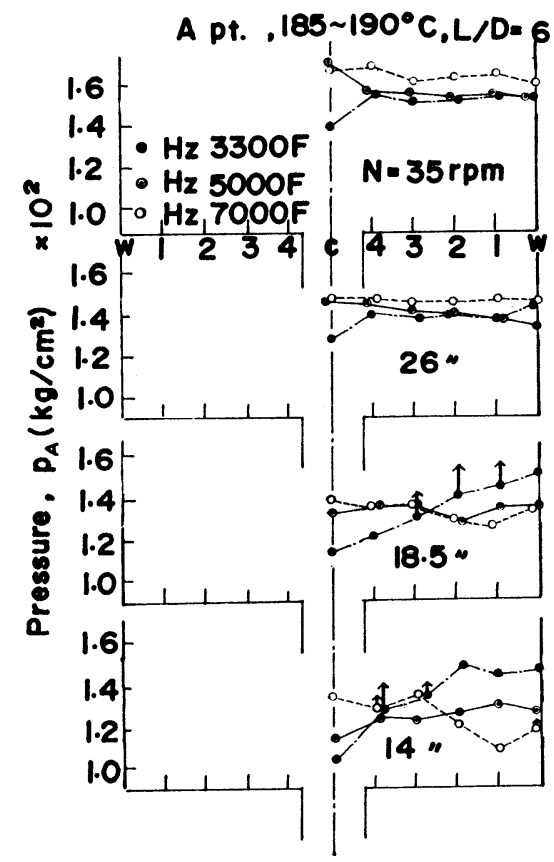

Fig. 12. A comparison of inner-pressure distribution curves for three kinds of samples under various shear rates at the measurement point $\mathrm{A}$. 


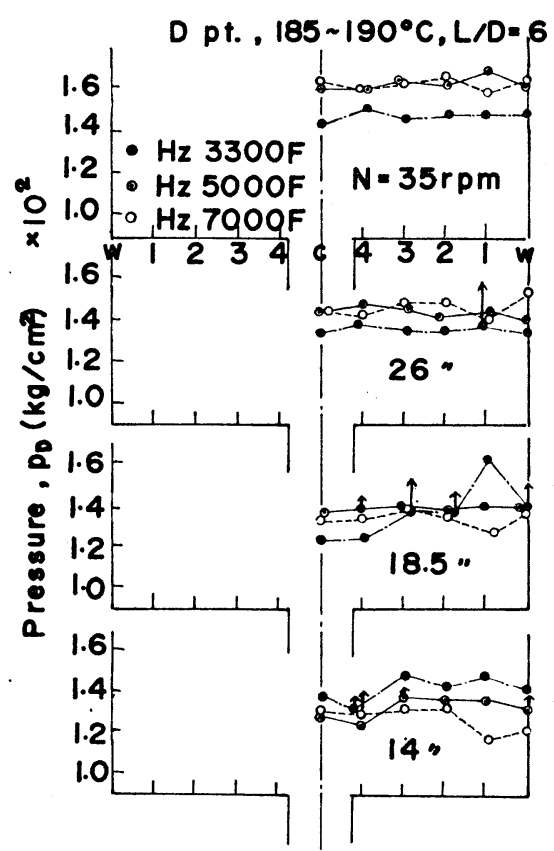

Fig. 13. A comparison of inner-pressure distribution curves for three kinds of samples under various shear rates at the measurement point $D$.

ともある. この傾向は流入口に近い測定レベルDよりも，より流 入口から離れたレベルAにおいて著しい。

\section{4. 考察}

\section{4・1 平均壁圧, 最高圧および最低圧の $\dot{\gamma}_{w}^{\prime}$ 依存性}

本実験における測定圧はいずれも，いわゆる一般的直交座標の 表示法 ${ }^{12}$ 亿従えば $\mathrm{p}_{22}$ (法線応力に該当した圧力成分) と考えら

れ, 流れ方向の押出圧力 $\mathrm{p}_{11}$ と相違している.

同じ流動条件のもとで, 種々の測定レベルでの壁面圧力 $\mathrm{p}_{w}$ の 平均を $\mathrm{p}_{W}$ (mean), その条件下で, 同一測定レベルでの圧力分 布における最高圧力と最低圧力とを $\mathrm{p}_{\max }$ および $\mathrm{p}_{\mathbf{m} \text { In }}$ で表わし， てれらの值と $\dot{\gamma}_{w}{ }^{\prime}$ との関係を検討してみた。，その一例を Fig. 14 に示す．ての図は主に $\mathrm{H}_{\mathbf{z}} 5000 \mathrm{~F}$ についてまとめたものであり， 一部比較のため $\mathrm{Hz} 7000 \mathrm{~F}$ も加えた.

この罒の示すように, $\mathrm{p}_{\max }$ と $\mathrm{p}_{\mathrm{min}}$ との差は, 本実験範囲内 では, 8〜 $30 \mathrm{~kg} / \mathrm{cm}^{2}$ の範囲にあって, $\dot{\gamma}_{w}{ }^{\prime}$ が増すほど小さくなる 傾向を示す。

すなわち， $\dot{r}_{w}{ }^{\prime}$ が比較的大きくなった状態においては, 内圧分 布曲線の形状は，平均化または平坦化する傾向にある。

またての $\mathrm{p}_{\max }$ は，一般に同一条件下で測定された平均壁圧 $\mathrm{p}_{w}$ (mean) よりも大きく, さらには $\mathrm{p}_{\mathrm{m} \ln }$ は $\mathrm{p}_{w}$ (mean) なら びに $\mathrm{p}_{\mathrm{w}}(\mathrm{min})$ よりも小さい。この傾向は壁面で測定された圧力 変化幅よりも, 内部における樹脂圧の変化幅の方がより大きいて とを示しいる。

平均壁圧 $\mathrm{p}_{\mathrm{w}}$ (mean) は, 一般に M.I. が小さいものほど大き い. すなち, 同種材料では分子量が大きく, 溶融粘度が増したも のほど $\mathrm{p}_{\mathrm{w}}$ (mean) は大きくなる.ただし, 同じ $\dot{r}_{w}{ }^{\prime}$ の条件下で も，試料によって正常流動域にあるか，あるいは spiralling な どの異常流動域にあるかによって, 遷移条件で生じる圧力急堿現

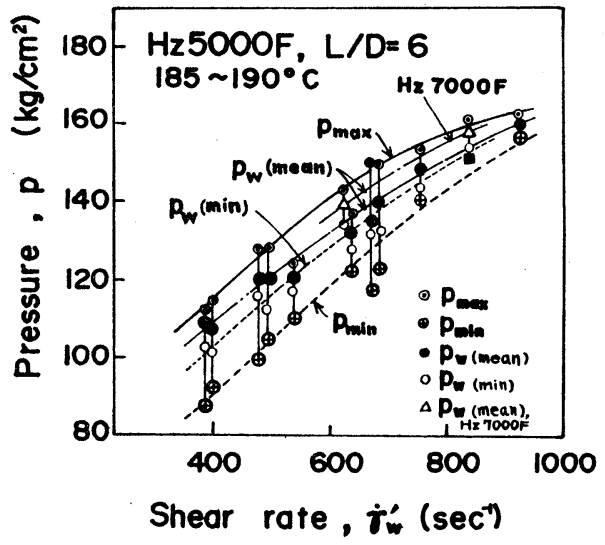

Fig. 14. The relation between shear rate $\dot{\gamma}_{w}^{\prime}$ and mean wall pressure $P_{W}$ (mean), maximum inner-presure $p_{\max }$, minimum inner-pressure $p_{\mathrm{m} \ln }$ and minimum wall pressure $p_{W(\mathrm{~m} / \mathrm{n})}$, respectively, for $\mathrm{H}_{\mathrm{z}}$ $5000 \mathrm{~F}$ at $185-190^{\circ} \mathrm{C}$.

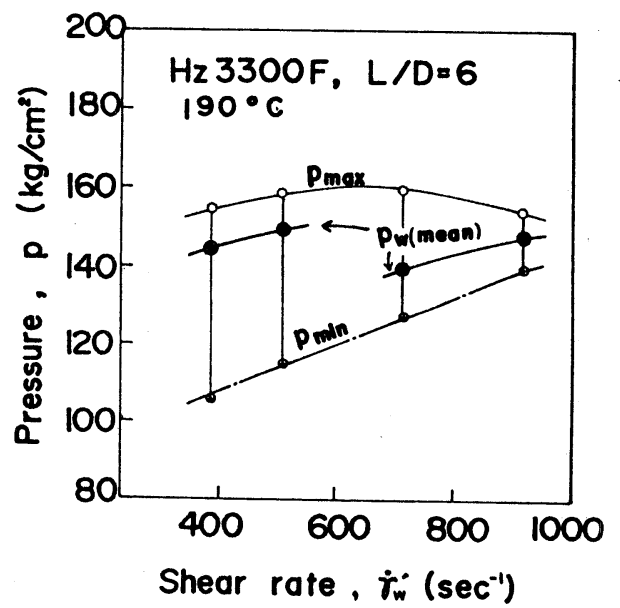

Fig. 15. The relation between shear rate $\dot{\gamma}^{\prime}{ }_{w}$ and mean wall pressure $P_{W}$ (mean), maximum inner-pressure $p_{\max }$ and minimum inner-pressure $p_{\mathrm{min}}$, respectively, for $\mathrm{H}_{z} 3300 \mathrm{~F}$ at $190^{\circ} \mathrm{C}$.

象をともなうとともあるので, 広い $\dot{r}_{w}{ }^{\prime}$ の領域内で上記関係が必 ずしも成立しない.

正常流動から spiralling への遷移条件で生じる $\mathrm{p}_{\mathrm{w}}$ (mean) の 急减現象は, Fig. 15 に示すように $\mathrm{Hz} 3300 \mathrm{~F}$ について著しいも のがある.

この図の示すように, $\mathrm{p}_{\max }$ と $\mathrm{p}_{\min }$ とでは， $\dot{r}_{w}{ }^{\prime}$ の増减に よる不連続性は， $\mathrm{p}_{\mathrm{W}}$ (mean) の曲線はど明瞭ではない， $\mathrm{p}_{\mathrm{W}}$ (mean) の同曲線が $\dot{\gamma}_{w}{ }^{\prime}=500 \sim 600 \mathrm{sec}^{-1}$ 近くで示す大きな不連続 性は, この条件を境とした二つの領域での流動形態の相違性を検 討する上に，一つの手がかりを示したものといえよう。

Fig. 16 は $\mathrm{H}_{\mathrm{z}} 3300 \mathrm{~F}$ の $190^{\circ} \mathrm{C}$ におけるリザーバー内部での圧 力変動個所を説明図的に示したものである，ただし，本図は本実 験範囲内で測定された圧力は, 流路の半分についてだけ測定した ものであるが，その分布形をより明示するため，流路の中心軸に 対し対称に図示したものである，ての図中で黒丸で示す個所は, 内圧変動を, その程度によって 3 種に分類して示したものである. 


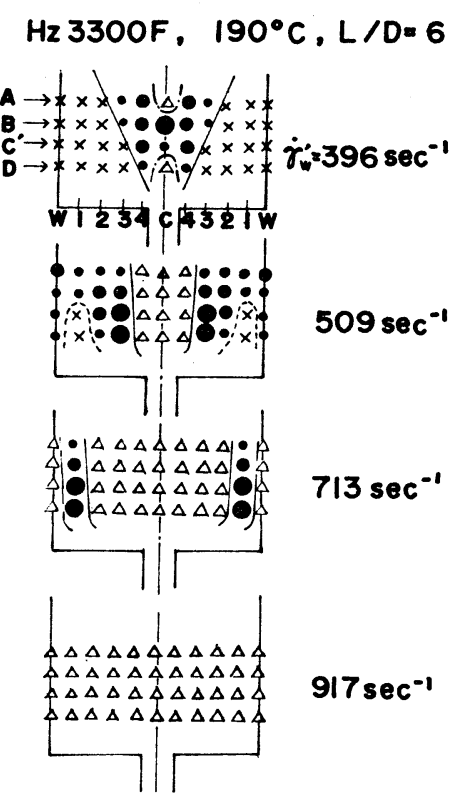

Fig. 16. A schematic figure of the positions with vibration phenomena of inner or wall pressure under various shear rates for $\mathrm{Hz} 3300 \mathrm{~F}$.

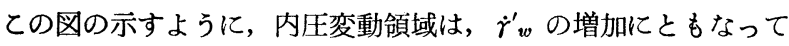
初期的には中心軸部分から，漸次壁面の方に押しやられ，遂には 消失する過程が表わされている.

この図の $\dot{\gamma}_{w}{ }^{\prime}=400 \mathrm{sec}^{-1}$ 程度の低いせん断速度領域内での内圧 変動個所は, 同図破線で示すように, 流入口を截頭頂角にもつ逆 三角錐体内（頂角は約 $30^{\circ}$ 近くにあると考元られる）飞存在する. この現象は既報で1)，偏光による流動縞の発生状態から類推した リザーバー内での流動模様あるいは White ら9)ならびに Han ${ }^{10)}$ らが示したりザーバー内流動模様によく似ている，てのように初 めには細孔直上の中心軸上で生じた内圧変動領域は，以後 $\dot{\gamma}_{w}^{\prime}$ の 増加にともなって漸次壁面へと移行する。.てれらの現象は，単に 壁面圧のみでは計り得ない樹脂内部の複雑な挙動を示したものと 考えるととができる.

またてれらの分布図に示すように，内圧変動を生じる境界領域 の内外にある内圧不変動部を, その発生形態上異種のものと考元, 初期 (内圧変動以前) を 1 st. 不変動部 (正常流動 ${ }^{1}$ に対応), 後 期 (内圧変動以後) を 2 nd. 不変動部 (異常流動) に対応) とし て区別した。

\section{4・2 細孔内流動状態と流量過多現象についての一考察}

以上のような諸結果から,また前報1) との関係から,リザーバー 内での圧力分布その他が，直接押出物形態に関連を及ぼしている と考えるととに基づくと，当然細孔内部での流動状態にも，上記 の諸現象に相当した影響がもたらされるものと考えることができ る.すなわち,リザーバー内に形成された内圧変動をともなった異 常現象などが，流動分子相互間の相対的なずれにはじまり，てれ がさらに成長発達し，分子間すべりのような特異な破壊面の発生 を生じたとすると，とのずれをともなった破壊面が細孔内流動過 程にわいても，流動にともなって移動するてとが想定できる．乙 れらについては，直接観察に基づいた現象的論述を前報において 示したが，本報ではさらに内圧変動性との関連から検討を加える，

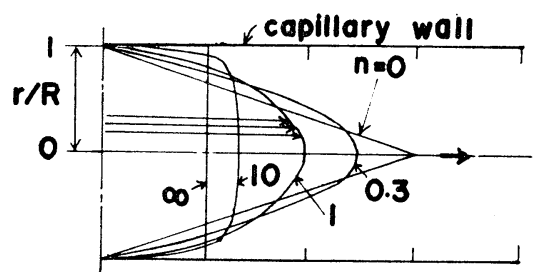

Fig. 17. The theoretical velocity profiles ${ }^{13}$ ) for polymer melts with various constants of power law index $n$, in a capillary estimated by the inclination of flow curve.
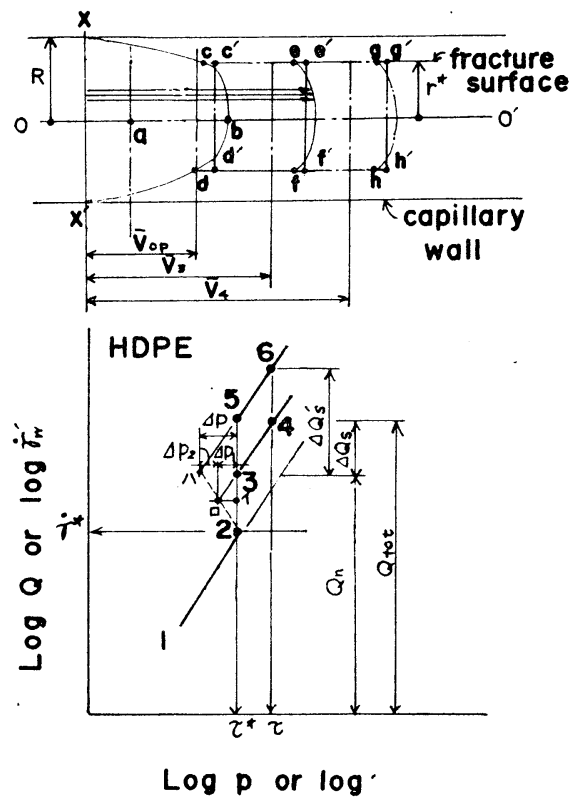

Fig. 18. The schematic figures of melt flow fracture of high density polyethylene; upper, the velocity profile in a capillary under the irregular flow, lower, the graphical analysis on melt flow fracture mechanism and flow rate excessing phenomena.

一般に円管流動における内部流動体の壁面から中心部に至る流 速分布は, Fig. 17 亿示すように，nによってその形態に差があり， $n$ が大きいものほど中心部が平坦化した，いわゆる栓流形態をと $ろ^{13)}$.

高密度ポリエチレンなどの溶融高分子の $n$ は一般に $2 \sim 4$ 程度 の值を有する。 また同一分子構造をもつ材料では, 分子量が増す ほど $n$ が大きくなる.

このような観点から円管内流動速度分布状態を眺めると，栓流 形態をとった場合に，壁面近くと中心軸近くとでは，流動分子の 応力状態あるいは流動形態に多少の差があるものと考えられる.

また Maxwell ら ${ }^{14)}$ が直接観察したように，最大せん断速度が， 壁面より少し内部において生じるてとは, 従来からいわれている 壁面せん断速度が最大になるとして結果を検討するより,より実 際的でありまた罗当であるようにも思われる。

したがって，上記の破壊面が細孔内部にもたらされた場合に， 壁面より多少内部に入った個所に発生したとの仮定に基づいて， 本報ではこれら溶融流動破壊性わよびてれらから派生すると考え 
られる流出量の過多現象を, 圧力変動性との関連において考察し てみた。

Fig. 18 は細孔内での流速分布と流出量過多現象について示し た説明図である.

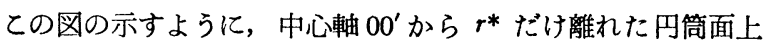
に，上記の発達したすべりをともなった破買面が発生したと考え ろ.

乙の場合の円管内流速は $x c b d x^{\prime}$ (すべりを生じない場合), $x c g$ $h d x^{\prime}$ (細孔内の容積に対するある比率ですべり部分を生じた場合) および $x$ cefd $d x^{\prime}$ (すべりを生じない場合と生じた場合の時間平均 的なるの)のように表わすととができる.

てれらの場合の流出量は，一般には次式で表わせる。

$$
Q_{\text {tot }}=Q_{n}+\Delta Q_{\text {s }}
$$

こてで, $Q_{n}$ は Fig. 18 の速度分布から求められる流出量, $\Delta Q$ 。 は破壊面によって生じた流出量增分とする.

また，式(引)は，平均流速によって表わすと次式のようになる。

$$
Q_{\mathrm{tot}}=\pi R^{2} \bar{z}_{\mathrm{op}}+c a \pi R^{2} L
$$

ただし， $\bar{v}_{\mathrm{op}}$ は平均流速， $a$ は紐孔内体積に対する流出量増加 割合, $c$ は単位時間内に発生する破壊面の発生回数とする.

これらの関係は，Fig. 18 下図に示すような流出量またはせん 断速度と圧力またはせん断応力の両対数目盛表示線図上で, (1) $\rightarrow$

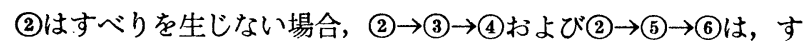
べり面の発生によって流出量が増加した場合を示している.

この線図上で， $\tau=\tau^{*}$ の(2)点に着目してみる，ただし， $\tau^{*}$ は 材料特有な限界せん断応力とする. この状態でリザーバー内で生 ビた破壊面が細孔内にまで発達し，大きなすべりを生じたとする と, 流速分布はすべり発生面で不連続となり, 流出量がその分だ け增す。

したがって，流動曲線上で(3)点または(4)点に移動したとすると， ての遷移過程では実際には外圧に対応した応力状態から, 局部的 に流出量増分だけ瞬間弾性回復を生じ，それにともなって内圧が 減少するととになる。したがって結果的には $\mathrm{p}=$ 一定または $\tau=$ 一定とならずに(2) 回またはののように状態変化をともなう。す

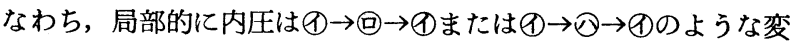
動を生じるととになる。またいったん内圧変動現象を通り越した

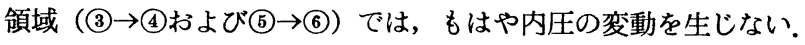
これら内圧変動性は，まだ定量的に定められるような段階ではな

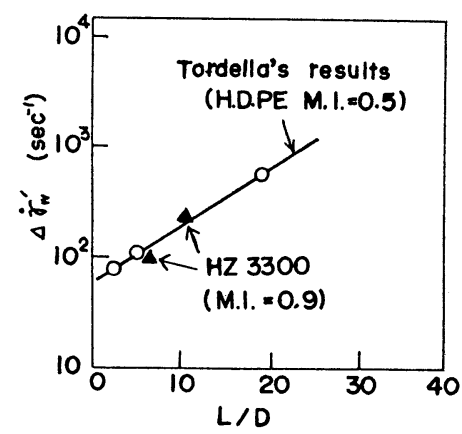

Fig. 19. The relation between the ratio of capillary length to diameter $L / D$ and the excessed shear rate with melt flow fracture $\Delta \dot{\gamma}^{\prime}{ }^{\prime}$, estimated by the results of Tordella and this experimental results of same authers,
いが，この種の現象の解明をある程度定性的に与えたものと考え られる。

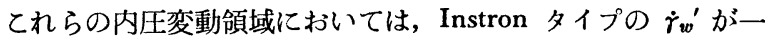
定の流動試験において, 圧力変動がとくに明瞭に把握できるのに

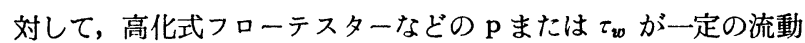
試験では, プランジャの変位振幅現象としてとらえられるという 経験的事実の理解にもある程度役立つものと考えられる.

またてのような細孔内でのすべりをともなった破壊面の形式が， 細孔長径比 $L / D$ によって変化するてとも想定できる.

この原理からみると，従来その起因が明らかとなっていない流 出量過多現象の $L / D$ 依存性もある程度定性的に解明するのに有 用な一つの手がかりが得られたと考えることができる。

Fig. 19 は Tordella ${ }^{4)} ら か ゙$ 示した細孔流動曲線から求めた流出 量過多量またはせん断速度増分 $\Delta \dot{r_{w}}{ }^{\prime}$ と $L / D$ との関係および筆 者らの行なった $\left.{ }^{3}\right)$ 同程度の M.I. の高密度ポリエチレンの同関係 を示したものである.

\section{5. 結論}

以上を総括すると，次の結論を得る。

(1) 一定流動条件下におけるリザーバー内圧は，総体的にはせ ん断速度の増大にともなって大きくなるが, 測定場所によって相 当倅化する.

（2）正常流動から spiralling（押出物がらせん形となる流動状 熊）への遷移状態でリザーバー内の局部に圧力が変動する個所が ある.

（3）圧力変動個所は, spiralling の初期状態では, 流入口近く の中心軸上近くで生じるが，せん断速度が増すにつれて，漸次壁 面に移行して行ぎ，またさらに高いせん断速度範囲では圧力変動 をもはや生じなくなる。

（4）とれらの圧力変動は，溶融粘度の小さい試料はど振幅も大 きく，またその周期も短い.

(5) リザーバー壁面で測定した圧力は，一般に内部で測定した 圧力の最高値より低く，またその最低值より高い．圧力分布曲線 にわける最高位と最低值の差は，せん断速度が大きくなるにつれ て小さくなる.

（6） spiralling の発生限界を境として，その上下のせん断速度 領域では, 平均壁圧に不連続性が生じる.

（7）とれらの圧力変動現象は，既報1) で示した流動破壊面の発 生形態と関連し，乙れを細孔流速分布において相対的ずれ面の発 生原理を導入した流出量一圧力関係曲線を用いてある程度の解明 ができた。

またてれらによって, 線状高分子構造体の流動過程における特 質の一つである流出量過多現象ならびにその細孔長径比の効果な どの起因をある程度解明し得る一つの手がかりが得られた。

〔付記〕本実験を遂行するにあたり，試料の提供を受りた三井 石油化学㑣の関係各位および有益な助言を戴いた慶応大学荒井定 吉教授ならびに実験に協力された当時の卒論学生, 桑島正一君に 厚く感謝の意を表する。

\section{文献}

1) Oyanagi, Y., Appl. Polym. Sym., 20, 123 (1973).

2) 山口章三郎, 大柳 康, 高分子化学, 28, 315, 623 (1971), 
3）大楖 康, 山口章三郎, 第22回高分子討論会前刷. III-357 (1973).

4) Tordella, J.P., Trans. Soc. Rheol., 1, 203 (1957).

5) Metzner, A.B., E.L. Carley and I.K. Park, Mod. Plast., 38, 133 (1960, July).

6) Cogswell, F.N. and P. Lamb, Trans. J. Plast. Inst., 35, 809 (1967).

7) Bagley, E.B., J. Appl. Phys., 28, 5, 624 (1958).

8) Tordella, J.P. J. Appl. Phys., 27, 454 (1956).

9) Ballenger, T.F., and J.L. White, J. Appl. Polym. Sci., 15, 1949 (1971).
10) Han, C.D., and L.H. Drexler, J. Appl. Polym. Sci., 17, 2329 (1973).

11）大楖 康, レオロジー学会誌, 2, 41 (1974).

12) 山本三三三, 物体の変形学 (日本材料学会編・材料科学々材 料工学), 9, 58, 誠文堂新光社 (1972).

13）岩楖茂夫, レオロジー〔基磁物理科学シリーズ 5)，58, 朝倉 書店 (1971).

14) Maxwell, B., and J.G. Galt, J. Polym. Sci., 62, S50 (1962).

15) Brydson, J.A., Flow Properties of Polymer Melts, Iliffe, London, 1970, Ch. 5. 